\section{La masonería en la Patagonia. Modernidad liberal y asociacionismo masón en Neuquén (1884-1907)}

Susana Bandieri

Susana Bandieri es Profesora Titular en el área de Historia Argentina de la Facultad de Humanidades de la Universidad Nacional del Comahue, e Investigadora del CONICET. Es también Directora del Centro de Estudios de Historia Regional -CEHIR- y Vicedirectora de la Unidad Ejecutora en Red ISHIR-CEHIR/CONICET en esa Universidad.

Dirección postal: Avda. Argentina 1400 (8300), Neuquén. TE (0299) 4490389.

e-mail: sbandieri@ciudad.com.ar

\section{Resumen}

Una variada bibliografía ha analizado las vinculaciones estrechas que existieron entre el asociacionismo masón y las tendencias liberales de los gobiernos de la segunda mitad del siglo XIX. Estas redes asociativas jugaron un importante papel a la hora de poner en práctica un proyecto de organización nacional y un modelo de país acorde con la modernidad liberal. Pero la penetración de una idea de sociedad laica y culturalmente homogénea, propia de esa modernidad, no prendió por igual y al mismo ritmo en las sociedades del interior, especialmente en las más tradicionales provincias argentinas ligadas al pensamiento católico. De allí que la masonería tenga una presencia mucho menos visible en el espacio público del interior que en el caso porteño. Pero los incipientes núcleos urbanos patagónicos, sobre todo los que fueron asiento de las nuevas autoridades territorianas, parecieron ofrecer alternativas válidas para consolidar cierto tipo de redes asociativas de carácter laico y liberal, como se evidencia en el caso estudiado.

\section{Summary}

A diverse bibliography has analyzed the close links between Masonic associations and the government's liberal tendencies during the second half of the XIX century. This associations network has played an important «role» during the national organization, when it was carried out certain kind of liberal policy model in correlation with the liberal modernity of the historical moment. The idea of a laic and culturally homogeneous society, according with that modernity, had no equal acceptance in all the societies of the different provinces of the country, mainly in those which catholic thought and traditions were very strong. Hence, Freemasonry had a lower presence all around the inland provinces of Argentina than in Buenos Aires.

Nevertheless, it was a little bit different in the new urban areas of Patagonia region, where the national territories' authorities settled. This article emphasize on this matter. 